УДК $273.13(0.044): 271$ «1781»

DOI: https://doi.org/10.33782/eminak2020.2(30).403

\title{
ОБІЖНИК ПРОТОІГУМЕНА ІНОКЕНТІЯ МАТКОВСЬКОГО ЧСВВ (29.01.1781 p.)
}

\author{
Ігор Кривошея ${ }^{1}$ Юрій Стецик ${ }^{2}$ \\ 1 Уманський державний педагогічний університет ім. Павла Тичини (Умань, Україна) \\ e-mail: igorkryvosheia@gmail.com; ORCID: https://orcid.org/0000-0003-1429-8293 \\ 2 Дрогобицький державний педагогічний ун-тет ім. Івана Франка (Дрогобич, Україна) \\ e-mail: stetsyk_u_o@ukr.net; ORCID: https://orcid.org/0000-0003-1795-687X
}

Окреслено актуальність питання для розвитку сучасної церковної археографії. Визначено рівень наукової новизни та методологічні засади публікації обіжника протоігумена Інокентія Матковського Чину Святого Василія Великого. Подано огляд епістолярних видань та друкованих і рукописних листів. Проведено джерелознавчу характеристику листа. Визначено призначення обіжника. Виокремлено структурні частини документа. Подано загальний огляд інформаційного наповнення листа.

Ключові слова: лист, обіжник, протоігумен, капітула, консульта

Постановка проблеми. У сучасних умовах розбудови мережі чернечих осередків Василіанського Чину в Україні постає необхідність у відроджені системи управління розпорошеними обителями. Адже сучасна система адміністративно-територіальної організації василіанського аскетичного життя на українських землях бере свої витоки з XVIII ст. Хоча основною датою утворення Василіанської Конгрегації вважається 1617 р., однак процес формування Чину набув завершеної організаційної форми аж у 1743 р. Саме із утворенням Руської (Святопокровської) провінції пов'язані процеси уніфікації та модернізації унійного чернецтва східного обряду. Вагому роль у цих процесах відігравали протоігумени, які керували всім чернецтвом, що мешкало на території провінції. Відповідно постає необхідність у вивченні адміністративного досвіду протоігуменів Святопокровської провінції, який відображений в листахобіжниках, що продукувалися ними.

Наукова новизна. В сучасній церковній археографії не віднаходимо спеціального корпусу документації в якій було б відображено листування протоігуменів Святопокровської провінції за 1739-1839 рр. Натомість віднаходимо тільки листування василіанських урядників із Апостольським Престолом ${ }^{1}$. У таких реаліях постає необхідність у заповненні певних лакун серед археографічних видань. Запропонований обіжник вперше був виданий у Почаївській василіанській друкарні (січень 1781 р.) ${ }^{2}$. Упродовж тривалого часу друкований обіжник мандрував із одного до іншого монастиря та переписувався до книги «актів домових», яка провадилися при кожній обителі провінції3 ${ }^{3}$ Відповідно до нашого часу дійшли як копії рукописних листів, так і

\footnotetext{
1 Welykyj A., Pidrutchnyj P. Litterae Basilianorum in Terris Ucrainae et Bielarusjae (1601-1760) // Annals of OSBM. 1979. Ser. II. Sec. III. Vol. I-II.

2 Інститут рукопису Національної бібліотеки України ім. В.І. Вернадського. Ф. 1. Спр. 1104. Арк. 53543в.

3 Biblioteka Jagiellońska w Krakowie. Rękopis 4502. K. 90-92 (zw).
} 
друкований оригінал обіжника. Співставлення різних списків із оригіналом дозволяє визначити географію поширення обіжника та дає змогу говорити про певну обізнаність із його змістом. Запровадження до широкого наукового обігу тексту обіжника дозволить дослідникам чернецтва ознайомитися із основними настановами протоігумена Інокентія Матковського.

Аналіз наукових досліджень і публікацій. Започатковані Юрієм Стециком та Ігорем Кривошеєю археографічні студії з історії Уманського василіанського монастиря й адміністративної праці протоігуменів Святопокровської провінції дозволяють систематизувати джерельний матеріал, який досі не запроваджений до наукового обігу4 ${ }^{4}$ Зокрема, Юрій Стецик започаткував серію видань обіжників протоігуменiв $^{5}$. I цей лист $є$ продовженням розпочатих археографічних публікацій. В історіографії досліджень Василіанського Чину зустрічаємо тільки загальні огляди обіжників протоігуменів Святопокровської провінціїб.

Джерельна база дослідження охоплює різні списки (як рукописні, так і стародруковані) листів-обіжників, які укладалися протоігуменом Інокентієм Матковським і його попередниками. Для верифікації інформації залучено постанови Тороканської провінційної капітули (1780 р.), розпорядження Білостоцької консульти (грудень 1780 р.) та повідомлення із обіжників протоігуменів (07.02.1777 р., 15.11.1778 р.)7.

Мета дослідження - проаналізувати структуру та зміст листа-обіжника Інокентія Матковського, протоігумена Святопокровської провінції.

Виклад матеріалу. Біографічні відомості про ієромонаха та протоігумена Інокентія Матковського подані у дослідженнях Юрія Стецика8. Тож зупинимося докладніше на джерелознавчій характеристиці листа-обіжника. Цей вид епістолярної документації набув популярності серед протоігуменів Святопокровської провінції в останній чверті XVIII ст. Ці обіжники укладалися з метою ознайомлення всіх настоятелів монастирів провінції з постановами провінційних капітул і розпорядженнями консульт. Якщо капітули виконували законодавчі та виборчі функції, то консульти були виконавчими органами управління.

Із виборами протоігумена водночас проводилося на провінційній капітулі обрання колегіального органу управління - провінційної управи: чотирьох консульторів і

\footnotetext{
4 Кривошея І., Стецик Ю. Джерела історії Уманського Василіянського монастиря: географія, походження та інформаційний потенціал // Історичні джерела в українському інформаційному й освітньому просторі: верифікація та інтерпретація: монографія / наук. ред. д.і.н. проф. 0.0. Салати. Вінниця: ТОВ «ТВОРИ», 2018. С. 24-37; Stetsyk Y., Kolpakov V. Administrative Authority of Protohegumens of Svyatopokrovska Province (1743-1780): Historical and Legal Aspects // East European historical bulletin. 2019. Issue 11. P. 56-65.

5 Стецик Ю. Циркулярні листи протоігумена Онуфрія Братковського як джерело регламентації чернечого життя у монастирях Святопокровської провінції (1772-1775 рр.) // Проблеми гуманітарних наук: збірник наукових праць ДДПУ. Серія «Історія». 2016. Вип. 38. С. 15-28; Стецик Ю. Лист-обіжник протоігумена Йосифа Моргульця до монастирів Святопокровської провінції (07.02.1777 р.) // Проблеми гуманітарних наук: збірник наукових праць ДДПУ. Серія «ІІторія». 2017. Вип. 40. С. 131-144.

6 Ваврик М. До історії василіянських капітул у Галичині в XVIII-IX ст. // Записки ЧСBВ. 1958. Серія II, Секція II, T. III (IX), Вип. 1-2. С. 46-68; Lorens B. Bazylianie prowincji koronnej w latach 17431780. Rzeszów: Wydawnictwo Uniwersytetu Rzeszowskiego,2014. 560 s.

7 Biblioteka Jagiellońska w Krakowie. Rękopis 4502.

${ }^{8}$ Стецик Ю. Реформаційний декрет протоігумена Інокентія Матковського (02.07.1781 р.) як джерело до вивчення чернецтва Уманського василіанського монастиря // Емінак: науковий щоквартальник. 2016. № 3 (15) (липень-вересень). Т. 1. С. 22-27.
} 
секретаря. Протоігумен не приймав одноосібних рішень, а постійно радився із своїми консульторами та настоятелями монастирів. Для цього він скликав дорадчі засідання, які отримали назву консульт, оскільки їхню основу становили обрані консультори (радники) провінції, які водночас призначалися настоятелями монастирів, а отже не могли проживати поряд із протоігуменом і секретарем у Провінційному Домі (на той час був у Почаївській Лаврі). Виходячи із таких обставин, протоігумен постійно мандрував до різних монастирів провінції, проводячи їхні візитаційні оглядини, а по їі завершенні скликав консульту для обговорення виявлених недоліків в укладі аскетичного життя. На цих зібраннях розглядалися поточні питання провінційного управління: розподіл фундацій і зобов'язань між монастирями, організація чернечих студій, розгляд дисциплінарних справ9.

Як постанови капітул, так і розпорядження консульт знайшли своє відображення у циркулярних листах (обіжниках) протоігуменів Святопокровської провінції. До нашого часу збереглися як рукописні, так і друковані листи. Зокрема, це обіжники протоігуменів Онуфрія Братковського, Йосифа Моргульця та Інокентія Матковського 10.

У структурі розглядуваного листа-обіжника можемо виокремити три тематичні складові частини: 1) постанови Тороканської провінційної капітули (1780р.); 2) розпорядження Білостоцької консульти, яка проводилася за спільною участю управ Галицької та Польської провінцій (грудень 1780 р.); 3) нагадування про розпорядження, які подані в обіжниках попереднього протоігумена Йосифа Моргульця (07.02.1777 р., 15.11.1778 р.).

У першій частині постанови Тороканської провінційної капітули зобов'язували настоятелів монастирів: до укомплектування бібліотек шляхом обміну літературою між обителями провінції; до підготовки документації та фінансової підтримки для прокураторів Чину у Варшаві та Любліні; до розподілу фінансових внесків для потреб Чину на три частини (1. для протоархимандрита, 2. для протоігумена, 3. на будівництво у Почаєві); до активної місіонерської праці.

У другій частині наведено розпорядження Білостоцької консульти (грудень 1780 р.), які поширювалися як на чернецтво Польської (Святопокровської), так і Галицької (Святоспаської) провінцій: щоб місіонери та професори, у вільний від виконання основного обов'язку час, залучалися до проповідницької праці у монастирському храмі; магістри новіціатів повинні дбати про розвиток у новиків здібностей до духовної науки та враховувати віковий ценз у складені аскетичних обітів і їх бажань щодо вибору провінції (для Польської провінції - 16 років, для Галицької провінції 24 роки); листування повинно носити офіційний характер, кожний лист повинен скріплюватися усталеною печаткою; по обіді потрібно співати гімн «Богородиця ти є лоза істинна», або ж інші церковні пісні присвячені святковому дню; щоб монахи, які переходять із однієї провінції до іншої, повинні мати із собою послушальний лист із дозволом протоігумена провінції, де він мешкав до цього.

У підсумковій частині листа звернута увага на виконання розпоряджень, які видавалися попереднім протоігуменом Йосифом Моргульцем: щоб не по одній, а по дві літургї̈ щомісяця відправляти за потреби провінції; щоб листи зберігалися у монастирській канцелярії, вписувалися до книги «Актів домових», перечитувалися кожної чверті року для монастирської спільноти та під час візитацій перевірялася їх наяв-

\footnotetext{
${ }^{9}$ Stetsyk Y., Kolpakov V. Op. cit. P. 56-65.

10 Стецик Ю. Циркулярні листи протоігумена Онуфрія Братковського... С. 15-28; Стецик Ю. Листобіжник протоігумена Йосифа Моргульця... С. 131-144.
} 
ність; щоб монахи не носили годинників із золотими і срібними прикрасами, оскільки це вважалося світською модою; щоб настоятелі уклали реєстр монастирської спільноти та відправили до Провінційного Дому для упорядкування каталогу всієї провінції; із дозволу єпископів настоятелі обителей могли підготовляти сповідників шляхом екзаменування ієромонахів спільноти для визначення їх здібностей. Список визначених здібностей чернецтва, разом із реєстром монастирської спільноти, необхідно було надсилати до Провінційної Управи 11.

Висновки. Виклад інформаційного матеріалу розглядуваного листа-обіжника структурований логічно та послідовно. У ньому подано основні нововведення, які запроваджувалися Тороканською провінційною капітулою та Білостоцькою консультою, які продовжували та доповнювали модернізаційні запровадження попереднього протоігумена Йосифа Моргульця. Активізація модернізаційних процесів була зумовлена суспільно-політичними змінами: першим поділом Речі Посполитої. Адже ця подія дала поштовх до поділу двох чернечих провінцій (Польської та Литовської) на чотири адміністративно-територіальні одиниці (Польську, Галицьку, Литовську, Білоруську). Про їх утворення офіційно проголошено на Тороканській генеральній капітулі (1780 р.), що також відображено у розглядуваному листі. 1780-1783 рр. був перехідним періодом щодо розподілу чернецтва та монастирів між новоутвореними провінціями. Відповідно в цей час відбуваються спільні засідання двох провінційних управ, що знайшло відображення у розпорядженнях Білостоцької консульти.

Перспективним напрямом дослідження вважаємо подальший пошук обіжників інших протоігуменів з метою укладення спеціального історико-археографічного збірника.

\section{REFERENCES}

Kryvosheia, I. \& Stetsyk, Y. (2018). Dzherela istorii Umanskoho vasylianskoho monastyria: heohrafia, pokhodzennia ta informatsiinyi potentsial [Sources of History of the Uman Basilian Monastery: geography, origin and information potential]. In Salata, 0.0. (Ed.). Istorychni dzherela v ukrainskomu informatsiinomu i osvitniomu prostori: veryfikatsiia ta interpretatsiia (pp. 24-37). Vinnytsia: TOV «TVORY» [in Ukrainian].

Lorens, B. (2014). Bazylianie prowincji koronnej w latach 1743-1780. Rzeszów: Wydawnictwo Uniwersytetu Rzeszowskiego [in Polish].

Stetsyk, Y. (2016). Reformatsiinyi dekret protoihumena Inokentiia Matkovskoho (02.07.1781 r.) yak dzherelo do vyvchennia chernetstva Umanskoho vasylianskoho monastyria [The reformation decree of the protoihuman Innocenti Matkovski (02.07.1781 year) as a source to the study of monastic Basilian monastery in Uman]. Eminak, 3 (15), Vol. 1, 22-27 [in Ukrainian].

Stetsyk, Y. (2016). Tsyrkuliarni lysty protoihumena Onufria Bratkovtskogo yak dzherelo reglamentatii chernechogo zytia u monastyriah Sviatopokrovskoi provintsii (1772-1773 roky) [The circular letters of the protoihuman Onuphrius Bratkovsky as a source of regulationg in the life of monastic (17721775)]. Problemy humanitarnykh nauk: zbirnyk naukovykh prats DDPU. Seriia «Istoriia», 38, 15-28 [in Ukrainian].

Stetsyk, Y. (2017). Lyst-obizhnyk protoihumena Yosyfa Morhultsia do monastyriv Sviatopokrovskoi provintsii [The encyclical letter of Joseph Morhulets addressed to the monasteries of Svyatopokrovska Province (07.02.1777)]. Problemy humanitarnykh nauk: zbirnyk naukovykh prats DDPU. Seriia «Istoriia», 40, 131-144 DOI: 10.24919/2312-2595.40.123244 [in Ukrainian].

Stetsyk, Y. \& Kolpakov, V. (2019). Administrative Authority of Protohegumens of Svyatopokrovska Province (1743-1780): Historical and Legal Aspects. Skhidnoievropeiskyi Istorychnyi Visnyk [East European Historical Bulletin], 11, 56-65. DOI: 10.24919/2519-058x.11.170700 [in English].

Vavryk, M. (1958). Do istorii vasyliianskykh kapitul u Halychyni v XVIII-XIX stolitti [The history of the

${ }^{11}$ Інститут рукопису Національної бібліотеки України імені В.І. Вернадського. Ф. 1. Спр. 1104. Арк. 53-543в. 
Basilian chapters in Galicia in the seventeenth and nineteenth centuries]. Zapysky ChSVV - Annals of OSBM (ser. II, sec. II, Vol. III (IX), issue. 1-2), 46-68 [in Ukrainian].

Welykyj, A. \& Pidrutchnyj, P. (1979). Litterae Basilianorum in Terris Ucrainae et Bielarusjae (16011760). Zapysky ChSVV - Annals of OSBM (ser. II, sec. III, Vol. I-II) [in Latin].

\section{Yurii Stetsyk}

(Ivan Franko Drohobych State Pedagogical University, Drohobych, Ukraine)

e-mail: stetsyk_u_o@ukr.net

ORCID:https://orcid.org/0000-0003-1795-687X

\section{Ihor Kryvosheia}

(Pavlo Tychyna Uman State Pedagogical University, Uman, Ukraine)

e-mail: igorkryvosheia@gmail.com

ORCID:https://orcid.org/0000-0003-1429-8293

\section{Circular of OSBM Protohegumen Inokentii Matkovskyi (January 29, 1781)}

The relevance of the issue for the development of modern church archeography is outlined. The scientific novelty level and methodological bases of epistolary documents publication are determined. An overview of epistolary publications is given. Different lists of the circulator are analyzed. The source description of the letter is carried out. The reason for the circular is clarified. The structural parts of the document are named. A general overview of the information content of the letter is given.

In the current conditions of creating a network of monastic centers of the Order of Saint Basil in Ukraine, there is a need for revived management systems of scattered monasteries. The modern system of administrative and territorial organization of Basilian ascetic life in Ukrainian lands originates in the $18^{\text {th }}$ century. The processes of unification and modernization of the union monasticism of the Eastern rite were connected with the formation of the Holy Pokrova Province. Protohegumens played an important role in those processes. Accordingly, there is a need to study their administrative experience, represented in the circulars.

The main goal of the study is to identify the structure and contents of the circular. The presentation of the information material of the letter is structured logically and consistently. It presents the main innovations introduced by the Torokan Provincial Chapter and the Bilostok Consulta. The intensification of modernization processes took place because of social and political changes (the first division of the Polish-Lithuanian Commonwealth). This event gave impetus to the division of the two monastic provinces (Polish and Lithuanian) into four administrative and territorial units (Polish, Galician, Lithuanian, Belarusian). Their formation was officially announced at the Torocan General Chapter (1780). 1780-1783 was a transitional period for the distribution of monasticism and monasteries between the newly formed provinces. Correspondingly, at that time the joint meetings of two provincial councils (Bilostok Consulta) took place.

We consider the further search for circulars of other Protohegumens to be a promising area of study in order to compile a special archeographic collection.

Keywords: letter, circular, Protohegumen, Chapter, Consulta 
Додаток 1

[Обіжник протоігумена Інокентія Матковського (Загорів, 29.01.1781 р.)] ${ }^{12}$

\section{Innocenty Matkowskowski Z. S. B. W., S. T. D., Opat Kaniowski, Prowincyi pod tytułem Nayświętszey Maryi Panny Prowincyał \\ Przewielebnym monasterów prowincyi naszey przełożonym, jako też wieleb- nym Oycom i Braci władzy naszey poruczonym, pokóy w Panu.}

K. 53 // Włożonego na Nas obowiązku przez wruczenie rządów Prowincyi Opieką Nayświętszey Maryi P[anny] zaszczyconey, tym usilniey dopelnić żądamy, im gorliwiey o ocalenie praw, czyli ustawów zakonnych, tak przez nas samych, iako i podręcznych nam $\mathrm{O}$ [jcow] i B[ratow] starać się mamy na których to praw ocaleniu gruntuie się doskonalość zakonna, a w tey coraz więcey postępowac każdy z osób zakonnych winien pod obowiązkiem sumnienia. Do tego ustawów zachowania, nie mało pomoże wiadomość obrad naszych zakonnych, mianowicie na kapitulach i konsultach mianych, gdzie niektóre przestrogi, potrzebne zalecenia, i nakłaniaiące do dobrego pobudki Oyców wybornych zdaniem układać się zwykły, nic nie odstępuiąc od przepisów tak S. Patryarchi Naszego Bazylego Wielkiego, iako też SS. Zakonu naszego Oyców w duchu i doskonałości zakonney gorliwych. Co zaś dawnieysze ustanowiły kapituly; częścią prasa onych drukarska obwieściła, częścią poprzedników naszych okolne oglosily listy. Podobnie co ostatnia kapitula generalna w Torokaniach miana, długim przeciągem czasu i pracy nie mniey gorliwie, iako doskonale ułożyla, trudno iest ninieyszym, ile krótkim, listem zamknąć i ogłosić, nad to że raz kapitula i oney chwalebne dzelo wyiściem z pod prasy drukarskiey exemplarzów rozeslać się maiących po wszystkich monasterach oglosi i obwieści. Sądziemy przeto, iż terażnieyszym listem naszym dosyć będzie oglosić przewielebnościom i wielebnościom waszym, tak zalecenia kapituly prowincyalney Torokańskiey, (na którey, iako iuż podobno wszystkim wiadomo, stanol podzial dwóch przedtym prowincyi na cztery, iako to Polskiey na Galicką i Polską, Litewskiey na Bialo-Ruską i Litewską) iako też niektóre ostrzeżenia i uwagi z konsulty w Bialymstoku odprawioney, za pomocą i wsparciem Nas Rady obydwoch prowincyi Polskiey i Galickiey. Nayuroczyściey tedy oglaszamy zalecenia kapituly prowincyalney Torokańskiey.

A nayprzód: Iż wspomniana kapitula obowiązuie mieyscowych przelożonych: 1mo: Aby biblioteki monasterów rządom swoim powierzonych pilnie zwidzieli, i gdy podwoione, lub potroione exemplarze iednego auktora upatrzą, innym monasteróm, podobnego exemplarza żadnego niemaiącym, za sprawiedliwą ostąpili cenę: lub też gdy w inney bibliotece drugego auktora podwoione exemplarze, znaydować się będą, wzamian za swoie podwoione exemplarze podlug sprawiedliwey taxy oddali Sess: 8va. Nro 1.

2-do. Ciż mieyscowi przelożeni, gdy interess iakowy prawny J. XX. prokuratorom pilnuiącym spraw w Warszawie, lub też w Lublinie poruczą: nie tylko mają zupelnie i dostatecznie przez papiery na to przygotowano, onych zainformować, i ściągaiące się do prawnych kroków czasu, mieysca i dziela, iuż zaczętego lub // K. 53 (zw) //

\footnotetext{
12 Інститут рукопису Національної бібліотеки України імені В.І. Вернадського. Ф. 1. Спр. 1104. Арк. 53-543в.
} 
maiącego się zaczać, okoliczności należycie przelożyć: ale też wydatek pieniężny na utrzymanie prawne interessu, przez nich lożony zupelnie nadgrodzić. Sess. 9-na ad finem.

3-tio. Gdy monaster nasz Poczaiowski dla rozpoczętey w nim fabryki utrzymować i żywić, iak by powinien, nayprzewielebnieyszego oyca naszego rządce Zakonu z calą radą jego nie iest zdolnym w tym czasie, innego kapitula obmyśleć srzodku do należytego utrzymowania teyże rady Proto-Archimandryczey niemogla, iak tylko do dawnieyszey zwyczayney skladki na podróżne potrzeby prowincyi, nową wyznaczyć skladkę w ten sposob: by dawnieysza skladka umiarkowaniem trzech części dzielona byla, a tak dwie części nowe do dawnieyszey caley skladki przydać się maią: naprzyklad: monaster który placil zlotych polskich sto, te na troie dzieląc, wyniesie każda część zlotych polskich trzydzieści trzy, groszy dziesięć, przeto łącząc do zlotych sta, części nowych dwie, to iest zlotych polskich sześćdziesiąt sześć groszy dwadzieścia: teraz będzie wyplacić obowiązany zlotych polskich 166 grosz 20. Podobny dział w większym i mnieyszym wydatku zachowany być ma. Tym zaś końcem te kapitularne oglasza się ulożenie, aby mieysc przelożeni wcześnie takową wygotowali skladkę, i w czasie kanoniczney wizyty wyliczyć ią i oddać bez żadney wymówki i zawodu gotowemi byli. Sess. 2-da Nro 1.

4-to. Pilnie roztrząsaiąc taż kapitula Torokańska, obowiązek funduszowy przez missye po klasztorach obydwoch prowincyi na nas, tak w Galicyi, iako też panowaniu Polskim, wlożony: aby XX. missionarze chwalebnych prac swoich dla pożytku zbawiennego dusz ludzkich, iako też dla wykonania chęci i myśli fundatorów swoich, gorliwie dopelniali: zalecić i przelożonych mieyscowych na sumnienia obowiązać nie zaniedbala, usilnie przykazuiąc staranność, z użyciem do tego wszelkich śrzodków, by funduszowe, gdzie są po klasztorach missye, corocznie z wszelką pilnością odprawiane byly. Gdy by zaś przez iakowy przypadek, lub niedostatek osób w którym, do missyi obowiązanym klasztorze, zbywalo na Zakonnikach do tey apostolskiey pracy zdolnych: na ów czas mieysca przelożony, z innego pobliższego klasztoru missionarzów sprowadzi nakladem monasteru swego: a tak chęciom pobożnych fundatorów dosyć uczynić obowiązanym będzie. Sess. 9-na Nro 5.

Powtóre: Na obradach naszych w klasztorze Bialostockim mianych, gdzie obydwoch Prowincyi Rada żgromadzona byla, w roku teraz skończonym 1780, w dniach ostatnich miesiąca grudnia ulożyliśmy, i tymże listem naszym okolnym oglosić nie zaniedbywamy, następuiących przestróg w ścisłym zachowaniu być maiących.

1-mo. Aby XX. Missionarze, gdy od prac missyi są wolnemi, ambonę domową w niedziele i swięta uroczyste dla pożytku zbawiennego ludzi na nabożeństwo do nas garnących się, zasłonić z wszelką pilnością starali się, mianowicie w tych monasterach, w których dla niedostatku osob każących niema sprawuiącego urząd kaznodzieyski: które to kazania tak przygotowane być maią: aby w czasie odprawuiącey się missyi tymże XX. Missionarzóm przydać się mogly. Do podobnego w miewaniu kazań obowiązku znać się maią XX. Professorowie w każdym czasie tym, którego od prac i zabaw szkolnych wolnemi będą, zwlaszcza gdzie na kaznodziei, i sposobnych do przepowiadania slowa Bożego zbywa. Przeto ieżeliby który z XX. Missionarzów, lub Professorów maiący zręczność i sposobność od wspomnianey chciał się uchylić pracy, nie maiąc w wymówieniu się należytey przyczyny: takowemu mieysca przełożony, podług proporcyi niedbalstwa, habitowego uiąć ma, i będzie powinien. Ciż XX. Missionarze corocznie w miesiącu styczniu, nas prowincyala uwiadomić maią, kędy, iak wiele, 
i z iakowego obowiązku missye odprawili; abyśmy latwiey docieć mogli, iako, i czyli wszędy funduszom missionarskim zadosyć się staie, którey powinności pilnic przestrzegać będą mieysca przelożeni.

2-do. Xięża Magistrowie nowicyatów dopilnować maią, aby nowicyuszowie nasi, zdolność do powiedzenia nauki duchowney maiący, w swięta uroczyste koleyno na kształ kazań, dawnieyszym zwyczaiem w refektarzu exorty miewali, a // K. 54 // w cerkwi dla pożytku ludzi na nabożeństwo zgromadzonych, nauki sposobem katechizmu odprawiali. Tey iednak usługi nie będą czynili z publiczney ambony, ale ze wszelką skromnością, w przytomności przydanego sobie socyusza, na ziemi stoiąc, odprawiać wruczone sobie dzieło będą, tak aby ztąd w nowicyackiey probie, i ducha ćwiczeniu żadney nie odnosili szkody. Ciż XX. Magistrowie w prowincyi naszey Polskiey, tak z obowiązku kapituly prowincyalney Torokańskiey, iako też z zalecenia ostatney konsulty naszey w roku ninieyszym $1781 \mathrm{w}$ Białymstoku pierwszych dni stycznia mianey, każdego z nowicyuszów, do uczynienia slubów zakonnych zabieraiącego się, pytać maią, ieżeli by professyą na prowincyą Polską lub też na Galicką uczynić chcieli: nie namawiaiąc, ani przymuszaiąc żadnego do tey albo owey prowincyi. Którzy ieżeli w prowincyi naszey Polskiey zostać usiłuią, bądż urodzeni w Galicyi, po zakończonych leciech szesnastu, do professyi przypuszczeni być maią. Jeżeli przeciwnie, urodzeni w Galicyi, do własney się oyczyzny powrócić, i na prowincyą Galicką professyą uczynić zechcą, przed dopelnieniem lat dwudziesto czterech wieku swego, do professyi uczynienia przypuszczeni nie będą, aby w tey mierze prawo nayiaśnieyszego ceserza Jgmci śwóy odebralo skutek.

3-tio. Jako dawnieysze obrady nasze, tak też Białostocka, ściśle i surowo wszystkich bez wyłączenia oyców i braci obowiązuie; aby listów żadnych, nie tylko do świeckich, ale też do żadnego z zakonników, nawet i przełożonych, pisywać bez wiedzy mieyscowego starszego, lub w niebytności, mieysce jego utrzymuiącego, nie wazyli się. Gdy zaś pisania listu nieuchronna wymagać będzie potrzeba, napisany przełóżonemu, lub w niebytności, namieśtnikowi iego do zapieczętowania ma być oddany. Co aby łatwiey uskutkować się moglo, wzmiankowana konsulta Bialostocka ten obmyślila sposób, i dozorowi czyli piłności mieyscowych przełożonych zalecila; aby w każdym monasterze naszym, iedna tylko dla wszystkich powszechna pieczątka byla, z tym okolo kolumny Swiętego Oyca Naszego na pisem: Sigillum Monasterii NN. Takową pieczątką listy, nietylko od młodszych, ale i od przełożonego pisane, pieczętowane być maią tak dalece, że gdy wspomnionego pieczątki wyrażenia na iakowym liście odbieraiący nie upatrzy tego listu rozpieczętować, a tym bardziey czytać niema, iako nie prawnie i przeciwko ninieyszemu rozrządzeniu pisanego. Nad to bez takowey pieczątki listy do przełożonych zakonu i prowincyi pisane, od nich odbierane i czytane nie będą chybaby komu z zakonników w podróży zostaiącemu zdarzyło się list $\mathrm{w}$ potrzebie napisać z przyciśnieniem używaniu pozwoloney pieczątki, na ow czas na liście wyrazić ma: $z$ podróży: a gdy i tego nie uczyni, list takowy niema być czytany.

4-to. W czasie po obiednim, gdy wszyścy, dla dostąpienia nato wyznaczonego odpustu, Nayświętszy Sakrament odwiedzaią, żaden hymnu poty zaczynać niema, poki przelożony, lub mieysce jego utrzymuiący znaku nieda, po którym zgodnym głosem wszyscy zaspiewaią hymn: Богородиця ти єси лоза істинна: albo też inny do wypadley uroczystości stosuiący się.

5-to. Aby się dosyć stalo rozrządzeniu kapituly prowincyalney torokańskiey, wymagaiącey, by osoba zakonna z iedney do drugiey prowincyi, na przyklad z naszey 
Polskiey do Galickey przenosząca się, miała list posłuszalny od prowincyala tey prowincyi, do którey się przenosi, oraz zezwolenie wyrażne nasze po drugiey stronie listu posłuszalnego, by się przeniosła. Przeto obowiązuiemy mieyscowych przełożonych prowincyi naszey, by żadnego zakonnika z monasteru swego nie wysylali za listem posłuszalnym, nie maiąc na nim wyrażoney z podpisem ręki naszey przeniesienia się woli.

Potrzecie. Listy przeszlych turnów okolne, iako to list w roku 1777 dnia 7 miesiąca lutego S.K. z Poczaiowa, drugi w roku 1778 dnia 15 listopada S.K. z Zahorowa, dane i w nich wyrazy i zalecenia, Przewielebnościom i Wielebnościom waszym przypominamy, wszystkie w nich ostrzeżenia pilnemu wykonaniu zalecamy, i tey mocy i wagi mieć chcemy iakoby od nas samych pisane i uroczyście ogloszone byly. Za zaś po ninieyszym podziele prowinciy wszystkie // K. 54 (zw) // obligi na iedną tylko naszą, są przeniesione, tym aby się zadosyć uczynić moglo, mieyscowych przełożonych obowiązuiemy, aby i sami i onych podręczni, iuż nie po iedney Mszy S. na intencyą prowincyi, ale po dwie na miesiąc bez zawodu odprawiali, w czym obowiązuiemy i obciążamy sumnienie każdego. Gdyby zaś iakowym przypadkiem listy okolne przeszlych turnow w którym monasterze nie znaydowaly się, tedy J. XX. przełożeni o nie starać się maią i razem z listem ninieyszym do aktów wciągnąć, iakoteż każdey ćwierci roku, by czytane były w refektarzu, przykażą: czego gdyby nie uczynili, w czasie wizyty kanoniczney spytani, naganieni będą. Mieć tuż pilne oko maią na Braci zegarki dla wygody noszących, by przy nich taflem przerabianych złotem lub srebrem, z okazałością światową, a barziey z pogorszeniem świeckich, nie nosili, i lańcuszków przy nich mianych z zanadrza dla chluby nie wystawiali.

Nakoniec obowiązuiemy mieyść przełożonych, aby iako nayrychley, każdy zgromadzenia swego, tak wieku, iako y professyi, iako naypilniey regestrzyk wygotował, i do nas przesyłał, tym końcem, aby katalog dostatecznie i prędzey osob prowincyi naszey mogl być wygotowany. Gdy nam od J. WW. Biskupów moc iest pozwolona, approbowania spowiedników po klasztorach, tey mocy mieyscowym udzielamy przelożonym, z obowiązkiem sumnienia, by każdego z podręcznych examinowali, i examinowanych zdolność nam razem $\mathrm{z}$ wyż rzeczonym regestrzykiem przesłali. Co wszystko scislemu zachowaniu gdy poruczamy, ninieyszy list dla większey wiary y wagi wlasną, przy zwykley pieczęci, podpisuiemy ręką. Dan w Zahorowie die 29 januarii v.s. 1781 Anno. Innocenty Matkowski ZSBW Opat Kaniowski, Prowincyał prowincyi Polskiey m[anu] p[ropria]. Orest Nachimowski ZSBW sekretarz Prowincyi $\mathrm{m}$ [anu] p[ropria]. L[ocus] S[igilli]. 